DOI: $10.17805 /$ trudy.2017.6.7

\title{
КУЛЬТУРНЫЙ ФРОНТ ГРАЖДАНСКОЙ ВОЙНЫ (ПО МАТЕРИАЛАМ ЦЕНТРАЛЬНОГО ГОСУДАРСТВЕННОГО АРХИВА МОСКОВСКОЙ ОБЛАСТИ)
}

\author{
О. Г. Жукова
}

Московский гуманитарный университет

Аннотация: В статье анализируется культурная политика Советской России в годы Гражданской войны: ликвидация неграмотности населения, развитие театра, литературы и искусства; поддержка культуры быта и культуры производства. Статья основана на материалах фондов Центрального государственного архива Московской области.

Ключевые слова: СССР; Гражданская война; культурная политика; культурная революция; ликвидация неграмотности

\section{THE CULTURAL FRONT OF THE CIVIL WAR (ON MATERIALS OF THE CENTRAL STATE ARCHIVE OF THE MOSCOW REGION)}

\author{
O. G. Zhukova \\ Moscow University for the Humanities
}

Abstract: The paper analyses the cultural policy of Soviet Russia during the Civil War: the elimination of people's illiteracy, the development of the theatre, literature, and art; the support for the culture of everyday life and for the culture of manufacturing. The paper is based on materials of the funds of the Central State Archive of the Moscow Region.

Keywords: USSR; Civil War; cultural policy; cultural revolution; elimination of illiteracy

В послереволюционные годы в России 1920-х годов был популярен такой жизненный анекдот. В одном селе организовывали колхоз, собирали подписи вступающих. Пришла молодая крестьянка и говорит: «Так как же я подпишусь, если я - неграмотная?!» А ей советуют: «Ты, Маша, поставь хоть крестик, а мы будем иметь в виду, что ты расписалась». Нарисовала Маша крестик, а через месяц, когда снова потребовалась ее подпись в какой-то ведомости, уже сама твердой рукой вдруг нарисовала в документе нолик. А на вопросы гордо пояснила: «А как же вы хотите? Я, чай, замуж вышла, фамилию сменила!» 
Трагикомичный сюжет дает представление, с каким «человеческим материалом» предстояло новой советской власти строить коммунизм общество равных, грамотных, образованных, целеустремленных людей прекрасного будущего.

Этот анекдот рассказал мне когда-то мой дед - Николай Иванович Жуков, в Великую Отечественную войну - знаменитый партизанский летчик, кавалер орденов Ленина, Красного Знамени, Отечественной войны двух степеней и многочисленных медалей, «за голову» которого фашистское командование обещало 50 тыс. марок, поместье с большим наделом земли и крестьянами и орден «железный крест» (История гражданской авиации СССР, 1983: 135).

Дед - уроженец деревни Минино Орехово-Зуевского района, знаменитой своей фабрикой с высокой красно-кирпичной трубой, на которой красовался год - «1879». Он, родившийся и выросший в семье потомственных подмосковных ткачей, прекрасно понимал, что именно новая власть дала возможность ему, простому деревенскому мальчишке, рано потерявшему мать, выучиться, стать уважаемым членом общества, дать высшее образование детям и внукам... По детству помнил он годы Гражданской войны, когда в их семью пришел голод, а шелкокрутильная фабрика-кормилица остановила свою работу в 1918 г. - у хозяев фабрики Алексея, Семена и Сергея Глазковых не было возможности доставлять шелк-сырец из Лиона и Милана, как прежде (ЦГАМО. Ф. 142, Оп. 1. Д. 92. Л. 53). Когда «бывшие», т.е. «господа», «белые», и вчерашние «чумазые» из «низшего сословия» - «красные», сцепились в смертельной схватке за свое будущее, победили красные. Не потому ли, что одновременно с боевыми действиями на всех фронтах не только против белых, но и против интервентов всех мастей, посчитали необходимым открыть еще один, самый важный фронт, - культурный? И начали самую важную революцию - культурную?

Ведь народ прекрасно представлял себе, какая жизнь ждет его, победи белые, он жил ею не один век. По данным переписи 1897 г., $78 \%$ населения Российской империи было неграмотным и в самом деле подписывалось крестиком. В формулярах переписи вопрос о грамотности стоял просто: «Умеет ли читать?»

А красные, казалось, смотрели далеко вперед и, начав с ликвидации безграмотности, электрификации и радиофикации страны, озаботились открытием новых школ, училищ, институтов и университетов. Сделали общедоступными музеями вчерашние дворцы. Дали толчок развитию кинематографа, живописи, литературы. Сделали «модным» чтение газет, посещение библиотек и театров. И даже закрывая храмы, чаще всего преобразовывали их в «храмы культуры»- клубы, библиотеки, кинотеатры, 
выставочные залы. Лозунг: «Культуру - в массы!» был тогда таким же важным, как стал в 1941-1945-м фронтовой «Все - для фронта, все - для победы!»

Но и когда Гражданская война отгремела, само понятие «культурный фронт» не сошло со страниц газет и журналов, с экранов кинохроники страны и в 1930-е годы индустриализации-модернизации, и, конечно, в 1940-е грозовые... А само понятие «культура» получило новые оттенки звучания, когда с высоких трибун и газетных страниц заговорили о культуре быта и культуре производства.

K сожалению, сегодня об этом вспоминают все реже, а некоторые договариваются до того, что, мол, не было в СССР никакой культуры и особенно, дескать, зажималась культура русская, а вокруг господствовала сплошная и беспробудная чернуха, интернационализм, губящий национальную идею. Недавно воспроизвел эту незатейливую мысль с экрана ТВ один нынешний «гражданский активист» и борец за православие, мать которого в 70-80-е гг. прошлого века возглавляла один из уникальнейших наших музеев под открытым небом. В нем были собраны советским государством уникальные образцы старинного русского деревянного зодчества, в нем проходили чудесные фольклорные праздники, на которые съезжались народные коллективы из многих областей и автономий России. Каждый - со своими песнями, обычаями, во всем многообразии национальной одежды. Да и сам он, юный тогда директорский отпрыск в красной рубашоночке и лапотках лихо отплясывал на сцене у старой мельницы. А вот теперь отчего-то обеспамятовал «Иванушка», забыл о деле жизни родной матери...

...Уникальные исторические документы, хранящиеся в Центральном государственном архиве Московской области (ЦГАМО), были переданы туда когда-то из Архива Октябрьской революции. Они повествуют о том, с какими трудностями столкнулось наше общество в послереволюционный период - безработица, голод, остановка промышленности, но и рассказывают о новых формах культурно-просветительской работы с населением, которые тогда были важны не менее чем поставки продовольствия и пуск предприятий. Любопытную ретроспективу культурной жизни подмосковных и столичных ткачей можно представить, изучая фонды ЦГАМО, относящиеся к деятельности профсоюза работников текстильной промышленности.

Итак, будем справедливы, отметив, что первые важные изменения в культурной жизни пролетариев и крестьянства стали происходить еще летом 1917 г., через полгода после Февральской революции и отречения царя власть на фабриках и заводах получают Комитеты рабочих депутатов. Среди протоколов Комитета рабочих депутатов фабрики «Товарище- 
ства мануфактур братьев И.А. Кудиных» встречаем сообщение, датированное 29 июля 1917 г.: «Богородская Земская Управа предложила чрез инструктора Павлово-Посадского района г-жу Комарову организовать при фабрике «Т-во М-р бр. И.А. Кудины» Культурно-просветительную комиссию» (ЦГАМО. Ф. 442. Оп. 1. Д. 30. Л. 10). Комитет принимает это решение единогласно. Новая Культурно-просветительная комиссия включает в себя одного представителя от администрации фабрики, от служащих -2 , от рабочих фабрики -4 плюс - педагогический персонал. Комитет принимает решение: «ходатайствовать о принятии на счет администрации расходов по школе для взрослых рабочих и подростков при двух учителях» (там же). Решено также ассигновать на школу единовременно 200 рублей, но учебники и пособия учащиеся должны приобрести за свой счет. Зато библиотека организуется на счет комитета фабрики.

А ведь буквально за несколько недель до этого важного решения Комитет справедливо решил вопрос об оплате труда своих совсем юных пролетариев, тех, кому и предстояло сесть за парты, приобретя учебники и пособия «на свой счет»: «Подростки, получавшие до июля пять рублей в день, так как несли работу взрослого мужчины. Было предупреждение со стороны администрации фабрики, что будут рассчитываться по три рубля в день, не считаясь с их работой. Комитет вынес: подростки, выполняющие работу взрослого, должны получать пять рублей в день, плату три рубля считать недопустимой» (там же. Л. 8).

А уже через месяц фабричный комитет начинает бороться за культуру общения своих рабочих. 9 августа рассматривается жалоба на рабочего Никифора Байкова, «который в присутствии всех рабочих отдела набивного и члена Комитета рабочих депутатов фабрики И. Лейкина сорвал и уничтожил объявление фабричного комитета о своевременном выходе на работу. Постановлено Комитетом набойщика Никифора Байкова лишить на три дня работы за разорвание объявления и поношение Комитета» (там же. Л. 12). Показательно, что именно такое наказание, как лишение работы оказывалось весьма действенным, ведь и зарплату рабочие получали поденно.

Рабочий-подросток Иван Потапов неоднократно заявлял в Комитет, что его избивает мастер-тамборщик Тимофей Ванягин. Дело решено передать Мировому судье Павловского Посада. «При допросе Ванягин сознался, что бил не раз: «Потапов не поспевает для нас работать». Комитет находил действия Ванягина - истязанием над малолетним» (там же).

А сколь непросто для разбирательства Комитета жалобы рабочих на взаимную грубость! Пожалуй, еще недавно и в голову бы не пришло делать этот вопрос достоянием общественности, а тут 17 августа Комитет рассматривает жалобу: «Оскорбление Иосифа Беспалова Федосьей Баба- 
риной. При допросе И. Беспалова Ф. Бабариной выяснилось, что в течение двух последних дней постоянно происходила ссора и выражение сквернословием обоих. Свидетели-ткачихи заявили, что И. Беспалов постоянно выражается бранно. Конфликт между И. Беспаловым и Ф. Бабариной ликвидирован путем примирения обеих сторон. Сделан строгий выговор Иосифу Беспалову, как первый случай жалобы на сквернословие. Выговор сделал и Ф. Бабариной» (там же. Л. 13).

Дальше - больше: «жалоба Ф. Белова на опальщика Павла за физическое оскорбление по лицу», «жалоба всего отделения тамборного на Тимофея Ванягина, что мешает работать в отделении и выражается сквернословием». И снова - строгое решение: «за неисполнение постановления Комитета о прекращении сквернословия и за постоянные ссоры в тамборном отделении, по показанию членов комитета и рабочих, лишить Тимофея Ванягина работы на два дня» (там же).

Но Комитету доводиться обсуждать и события, свидетельствующие о величайшей сознательности своих сослуживцев: «Деньги, найденные в фабрике 4 июля с/г П. Михайловым, и пожелавшим возвратить их потерявшему, за ненахождением хозяина денег передаются в распоряжение Комитета. Комитет постановляет передать деньги П. Михайлову за его честное отношение к чужой собственности...» (там же).

После событий Октября 1917 г. культурно-просветительские комиссии и отделы при фабриках и профсоюзах текстильщиков становятся массовым явлением, получают централизованное управление, их работа координируется и направляется властью. Строго проверяются финансы. Так, в Смете расходов культурно-просветительного отдела при Богородском отделе профсоюза текстильщиков за 1918 г. указывается, что в этом развитом текстильном районе Подмосковья насчитывается около 70-ти фабрик (к сожалению, многие предприятия тогда останавливались из-за недостатка сырья). «Принимая во внимание приход денег в Союз около 70000 р. ежемесячно», отдел заявляет, что «этих денег львиная доля должна быть израсходована на культурно-просветительную деятельность» (ЦГАМО. Ф. 142. ОП. 1. Д. 47. Л. 16).

Отдел намечает грандиозный фронт работ: «все фабрики... требуют немедленной организации: народных домов, библиотек, читален, лекций и т. д. и все эти потребности в культуре трудно удовлетворимы», но все же принимает смету расходов на культурные нужды текстильщиков: «канцелярские расходы - 800 руб., организационные - 1000 руб., покупка книг для библиотеки -8200 руб., устройство народных домов или выдача субсидий на их устройство - 5000 руб., на устройство яслей и очагов 8000 руб. запасной капитал - 2000 руб.» (там же).

А в недалекой от Богородска (ныне - Ногинска) столице профсоюз ра- 
бочих по выработке текстильно-волокнистых веществ Московского центрального округа уже 4 января 1918 г. пишет заведующему Московским художественным театром: «Культурно-просветительная комиссия при Союзе текстильщиков убеждается, какое огромное влияние на развитие личности имеет искусство. Московский Художественный театр в этом отношении может оказать неоценимое влияние. Ввиду того, что доступ в Художественный театр по разным причинам недоступен для работников Культурно-просветительной организации, Комиссия обращается к вам с убедительной просьбой не отказать предоставить в распоряжение ея билеты на очередныя представления для соответствующаго распределения. Для личных переговоров по этому вопросу Комиссия уполномочивает своего секретаря. Фрица Фрицевича Килевица» (ЦГАМО. Ф. 163. Оп. 1. Д. 76, Л. 1а).

В феврале 1918 г. с такой же просьбой профсоюз обращается уже к заведующему Малым театром: «Центральное правление просит Вас предоставить в распоряжение Культурно-просветительной комиссии Союза билеты на очередные представления Малого театра. Ввиду громадного значения в культурно-просветительной работе просим удовлетворить нашу просьбу» (там же. Л. 2).

В июне 1918 г. Богородское отделение профсоюза текстильщиков рассылает по вверенным ему фабрично-заводским комитетам строгий циркуляр: «прислать именныя списки всех рабочих и служащих вашей фабрики, разбив их на категории: малолетние, подростки, взрослые и инвалиды, а также же и по степени их специальности. Сведения эти Союзу необходимы в самый наиближайший срок, все фабрично-заводские Комитеты, не представившие настоящих анкет, будут привлечены к суровой ответственности как за саботажъ» (ЦГАМО. Ф. 142. ОП.1. Д. 48. Л. 13; (подчеркнуто и подписано от руки в документе. - О. Ж.).

Очевидно, что строгая ревизия всех текстильщиков по возрасту и состоянию здоровья была необходима для дальнейшего решения об обучении и повышении квалификации малолетних пролетариев. Этого требовал от всех профсоюзов страны и Наркомат просвещения. Так, например, 23 июля 1918 г. Отдел народного Просвещения Совета Рабочих депутатов Городского района г. Москвы сообщает в профсоюз работников и работниц по обработке текстильно-волокнистых веществ, что намерен организовать занятия для подготовки работников по дошкольному и внешкольному образованию, основанному на трудовом принципе: «Мы считаем необходимым в полном согласии с программой Российской коммунистической партии, подготовить из детей пролетарской массы всесторонне развитых людей, с первых шагов своей сознательной жизни вырабатывающих в себе способность к любому труду» (ЦГАМО. Ф. 163. Оп. 1. Д. 76. Л. 11).

Отдел намечает группы по лепке, рисованию, ручному труду, апплика- 
ции, картонажным, папочным и переплетным работам, столярному делу, выпиливанию, выжиганию, металлопластике, шитью, рукоделию, художественной вышивке, фотографии. Веянием непростого времени становится включение в программу групп таких умений, как работа с бросовым материалом, плетение корзин и вообе плетенье, как переходу к ткацкому станку и тканью, сапожному ремеслу, шитью обуви из материи и веревок.

Разъясняя свою идею работникам профсоюза, сотрудники наркомата просвещения отмечают: «Параллельно с приобретением знаний по ручному труду должна идти работа по изучению материалов, инструментов и т. д. с точки зрения их применения в работе с детьми. Работа должна быть лабораторной, анализировать все, наблюдать, изучать, проверять, исправлять» (там же).

И, наконец, заключительное и самое главное: «Для участия в этой работе просим прислать товарищей соответствующей специальности, работа которых будет оплачиваться. Нам нужен не политический агитатор, а интеллигентный товарищ, знакомый со своей специальностью» (там же).

В августе 1918 г. по всем отделениям профсоюза текстильщиков рассылается информация о создании литературной студии Пролеткульта, которая открывается 1-го сентября: «Задачи студии - литературное воспитание рабочего писателя и рабочего читателя. Студия разделяется на два подотдела. Образовательный отдел будет способствовать ознакомлению рабочего класса с литературным наследием прошлых эпох. <...> будут прочтены курсы по истории русского театра и истории русской культуры. Лекторами Общеобразовательного отдела состоят: тов. Богданов, тов. Лебедев-Полянский, тов. Столяров и др. Специальный отдел стремится ознакомить рабочего писателя и рабочего читателя с техникой литературного творчества и помочь ему овладеть ею. <...> будут производиться занятия по теории стихосложения, критики и журналистики и по поэтики русской устной и письменной речи. Лекторы тов. Зайцев, тов. Брендер, тов. Шершеневич, тов. Ходасевич, тов. Эйхенгольц и др. В студии будут вестись практические занятия с начинающими авторами и журналистами и будут разбираться представляемые практические произведения рабочих писателей» (ЦГАМО. Ф. 48. Оп. 1. Д. 1-2. Л. 51).

Уже через месяц, 1 ноября 1918 г. Московский Пролеткульт готов рапортовать о проделанной работе по воспитанию рабочего писателя и рабочего читателя, приглашая на спектакль-концерт 6 ноября в помещении театра «Драмы и комедии» на Тверской «в ознаменование события Великих Октябрьских дней» (ЦГАМО. Ф. 163. ОП. 1. Д. 76. Л. 3).

В программе драматического отделения - «Восстание» Верхарна, декламация и пластические номера: «Мрак», «Порыв», «Марсельеза». В музыкальном отделении концерта - «хор под аккомпанементом оркестра 
народных музыкальных инструментов исполнит революционные и народные песни» (там же).

Но песнями, как говориться, сыт не будешь. И культура быта столь же важна, как и культура в высоком понимании этого слова. Поэтому Союз текстильщиков Московской области 9 декабря 1918 г. обращается в Московский Продовольственный комитет и «настаивает открыть детские очаги /Рыкунов пер. при Красс.-аппр.-ке/ и в доме, принадлежащем Союзу /Покровка, 42/» (ЦГАМО. Ф. 163. ОП. 1. Д. 76. Л. 6). А в связи с тем, что «организуется общежитие и клуб для приезжающих из провинции ответственных работников, делегируемых отделениями и комитетами по делам Союза», президиум Союза текстильщиков Московской области просит: «в виду невозможности получить в частной продаже необходимых предметов столовой и чайной посуды, <..> оказать содействие на получение следующих предметов столовой посуды: тарелки плоския 100 комплектов, глубокие миски - тоже» (Там же).

Растут культурные запросы рабочих, и 24 декабря 1918 г. фабком знаменитой Богородско-Глуховской мануфактуры просит Богородское отделение Союза текстильщиков: «отпустить на культурно-просветительныя нужды 50.000 руб. Как-то: для библиотек, на организацию художественной студии, для партийной школы, для лекций, для открытия музыкальных курсов, для создания детских площадок и садов» (ЦГАМО. Ф. 163. Оп. 1. Д. 75. Л. 6).

Инициативы с мест поддерживаются новыми решениями сверху. В декабре 1918 г. по всем фабричным комитетам рассылается письмо Центрального Правления Союза текстильщиков с копией программы курса Гражданской Грамоты в школах для взрослых: «В целях преподавания курса гражданской грамоты является развитие целостного миросозерцания в духе научного социализма и коммунизма и активно сознательного отношения к происходящим мировой войне и революции. Преподавание ведется строго научно, способствуя научно-критическому развитию ума, приучая к самостоятельному систематическому размышлению. Преподавание должно идти в форме живых бесед на отделение, наиболее близкое современному моменту и наиболее способствующее общему развитию слушателей <...> с историческим освещением в порядке ретроспективном» (ЦГАМО. Ф. 142. ОП. 1. Д. 48. Л. 45).

Темы занятий включают несколько важных для текущего момента направлений: «Экономический строй Советской России и вообще развитие хозяйственных форм»; «Город и деревня в Советской России в их хозяйственном взаимоотношении»; «Классовая борьба и социализм. Современная мировая война и ее роль в международной борьбе труда и капитала»; «Российская Федеративная Советская Республика»; «Церковь и 
государство» (там же).

С такими широкими культурно-просветительскими задачами встречала 1919 год страна, ведущая войну на два фронта - с белыми и интервентами. Но, как показывают архивные документы, и ровно через 10 лет задачам культурного строительства в советском обществе уделялось важнейшее значение, особенно культуре быта, культуре производства и даже культуре потребления.

...Снова обратимся к практике профсоюза текстильщиков Москвы и области. Важной вехой стал для него Первый московский областной съезд Союза текстильщиков, прошедший в первых числах сентября 1929 г. Председательствовал на нем Александр Трофимович Марков, в ту пору 52-летний советский и партийный деятель, председатель ЦК Союза текстильщиков, член Президиума ВЦСПС. В дореволюционном прошлом ткач Прохоровской Трехгорной мануфактуры, участник революционного движения с далекого 1895 г. В 1918-1922 гг. - председатель Исполнительного комитета Орехово-Зуевского уездного Совета.

Выступая перед делегатами Съезда Александр Трофимович на примере хорошо знакомого ему Орехова-Зуева вспоминает, какие изменения произошли в обществе за прошедшие 10 лет: «У нас в Московской области было село Орехово - да и это село было разбито между двумя губерниями. В то же время такие незначительные пункты, которые ничего из себя не представляли в экономическом отношении как Руза и др., где, кажется, не было ни одного рабочего, а лишь помещики, купцы, мещане, кулаки и проч., которые не имели никакой промышленности, именовались городами, эти помещичьи и мещанские города, не имевшие никакого экономического значения пользовались всеми культурно-коммунальными благами. Там были парки, водопроводы, канализации, освещение и т. д., тогда как рабочие центры ничего этого не имели. Вы помните, как наши текстильщицы в Орехове ночью ходили на стирку за 4-5 верст? Стало быть, на рабочее население старое правительство почти никакого внимания не обращало» (ЦГАМО. Ф. 165. Оп. 1. Д. 3 Л. 4).

Тем не менее, делегаты Съезда вполне в духе того времени высказывают ряд критических замечаний относительно продуктового снабжения, зарплат, состояния рабочих мест. И Марков в заключительном своем слове не боится разговаривать с делегатами откровенно. Речь его пестрит понятными текстильщикам понятиями и оборотами, она убедительна и проста, не лишена юмора и иронии. Представляется, что именно такая речь могла бы органично прозвучать из уст актеров Михаила Ульянова, Евгения Матвеева, Петра Вельяминова, Евгения Урбанского, Николая Еременко-старшего в кинофильмах, ставших советской киноклассикой: «Конечно, тяжело, и, разумеется, лучше было бы, если бы были жилища 
вокруг фабрики, были клубы, были ясли, детсады, площадки, стадионы и т. д. Но пока этого нет, а надо усиленно работать, чтобы все это было. Во имя того пятилетка и составлена, чтобы ее выполнить и облегчить эти культурно-бытовые наши условия. Ведь также выступали в 19 году, когда говорили, что «куда вы нас посылаете на работу, вы сперва нам хлеба дайте». А мы говорили: «Независимо от того, есть хлеб или нет, а работать нужно». Иногда и без хлебца работали, иногда, как здесь говорили, «вошь кусала», а мы все-таки продолжали работать. И ведь не ошиблись. Стало быть, вопрос идет о том, что пятилетний план как раз предусматривает смягчение и жилищного кризиса, и культурно-бытовых неурядиц. Во имя того нужно и дальнейшие планы выполнять» (там же. Д. 4 Л. 121).

Доскональное знание дела проявляет старый текстильщик и в вопросе воспитания: «Дальше, надо прямо сказать, и это говорилось не раз в наших резолюциях, что надо привлекать самих рабочих к организации на кооперативных началах яслей, садов и всего чего угодно. Ведь, подумайте же - каждый семейный наш текстильщик имеет ребенка, но не имеет возможности послать его в ясли. Но ведь родители уходят от ребенка. Каждый из них содержит няньку. А я знаю, что значит иметь няньку. Она тебя осрамит, то ее не так положишь, то ее не так посадишь, то она ребенка ущипнула, то ее ребенок ущипнул. Сколько скандалов, сколько неряшливости, и во что это обходится? А про няньку ведь говорят теперь, чтобы она была членом Союза Нарпит. Нарпит старается заключать на нее договор, вплоть до спецодежды, отпусков и т.д. Подсчитайте, во что вам обходится это неряшливое содержание вашего ребенка? А что если бы сложились в этаже или в целой казарме на кооперативных началах, внесли содержание той няньки, как свой пай ежемесячный, организовали бы на кооперативных началах ясли или сад?» (там же).

Далее Марков подводит своих слушателей к мысли, что культурносоциальные запросы населения растут в прямой зависимости от роста уровня его доходов и улучшения жизни, и напоминает о первых революционных годах: «А ведь население-то растет, ведь смертность у нас падает, культурный уровень и экономическое благосостояние рабочего класса, всего населения улучшается. Ведь, чтобы мы не говорили, живем-то мы лучше все-таки, чем в довоенное время. Кроме того, что у нас заработок несколько выше, чем в довоенное время, мы сейчас накладными расходами на зарплату обеспечены на предмет черного дня. Или ты заболел, или - женщина беременная, - платят. Мы говорим: «Рожайте, бабы! Пионеры нужны! Самое лучшее богатство - это здоровое и полное население». На предмет безработицы и т.д. ведь рабочее население обеспечено. У нас рабочие ведь денежки свои мало кладут в банк на черный день, а все это тратят на лучшее питание, на кроватки с култышками, а раньше спали на 
таких кроватках, чтобы, по меньшей мере, в них миллиарды клопов размещалось. Где уж тут было думать о лучшем питании!» (там же).

Но, понимая, сколь болезнен продуктовый вопрос для большинства населения страны, А. Т. Марков снова разъясняет попросту: «Толкуют, что нет мяса. Охотно верю. Но, только теперь, поднявши свой культурный уровень, рабочий понял, что ведь мясом-то питаться дешевле всего, потому что если ты пару фунтов мяса сварил на семейство /а я раньше по полфунта мяса варил/, то целую котловину щей наваришь. Нахлябался щей, а потом по животу стучишь, а он дуется, и целый день дуется, и довольно хорошо дуется. Отсюда потребность в мясе возросла. Ведь его сейчас не кушает только ленивый. А ведь раньше как было? Вот мы это не учитываем» (там же).

«Я сам - старый текстильщик, живу на свете 52 года. И вот я скажу вам, что 9 месяцев в году рабочий класс в абсолютном большинстве мяса не ел до Революции. Я вам скажу, как это было. В году 365 дней, 52 недели, 52 среды и 52 пятницы. Это 104 дня. Потом великий пост 8 недель. Потом рождество - тоже пост 8 недель. Затем Петровский пост, Успенский пост и т. д. Ведь мы все постились. Собирались получить манну небесную на второе пришествие. <...> У текстильщиков зарплата отстала и то жалуются, если не каждый день готовят себе обед из мяса. По утрам, говорят, масла нет. Поверьте, товарищи, в довоенное время я никогда не ел масла с хлебом. И привычки такой у нас не было. Это все хорошо, что мы имеем большие потребности и возможности питаться. Но все это надо обосновать, надо все это экономически обеспечить. Для этого надо построить колхозы и совхозы. Надо дать крестьянам машины, а то они до сих пор пашут допотопными сохами. <...> Тут крестьянам поможет только великий революционер - трактор!» (там же).

Видимо, зал воспринимал слова председателя с одобрением, да и сам он остался доволен реакций зала: «Вы глядите, какие текстильщики хорошие люди. Я всегда говорил, что это - лучшие из людей. Ведь если им хорошенько все это вовремя рассказать, так ведь это люди с энтузиазмом. Наша беда, что мы им ничего не говорили или говорили очень мало. Давайте создадим такой Областной комитет и ему в напутствие скажем, что если ты, балда, к следующему съезду будешь также руководить, так мы тебя возьмем так, что тебе небо с овчинку покажется. Вот как надо ставить вопрос!» (там же).

Итак, Первый московский областной съезд Союза текстильщиков, созванный накануне начала индустриализации СССР, не только наметил важнейшие цели и первоочередные задачи текстильной промышленности страны, но и поставил важнейшие культурно-бытовые вопросы.

В те же сентябрьские дни 1929 года, на местах, например, в хорошо 
известном А. Т. Маркову Орехово-Зуево, на заседания Президиума окружного совета профсоюзов предлагается всем окротделениям союзов: «вменять в обязанность тем фабзавкомам и месткомам на предприятиях и в учреждениях, коих работают неграмотные и малограмотные члены профсоюзов, живущие в деревне, проверить ликвидацию неграмотности и малограмотности среди них, и наметить практические меры для полного охвата их ликбезом» (ЦГАМО. Ф. 357. ОП. 1. Д. 2. Л. 18).

Понимая, что не так-то просто усадить серьезных отцов семейств и их жен - работниц и хранительниц многодетных семейных очагов за школьную парту, профсоюз ищет новые формы культурной работы с таким непростым контингентом: «Считать целесообразным организацию среди неграмотных и малограмотных семейных вечеров, экскурсий, предоставления бесплатных мест в театр и т. п. <...> Предложить в 2-недельный срок проработать вопрос об освобождении обучающихся неграмотных и малограмотных от общественных нагрузок, мешающих им проходить обучение» (там же).

Понимая всю важность печатного слова, профсоюз текстильщиков предлагает использовать прессу для популяризации важности идеи ликбеза: «Отмечая неудовлетворительное участие клубов в ликвидации неграмотности, предложить им отразить в полной мере в своей работе проведение ликбеза. Начать широкое освещение хода ликвидации неграмотности в окружной газете “Колотушка”. Использовать для самого широкого общественного мнения вокруг ликвидации неграмотности приезд в Орехово-Зуево Н. К. Крупской» (там же).

Понимают профсоюзные деятели и то, что добиться стопроцентной грамотности рабочих недостаточно. Время требует еще и повышения уровня их квалификации. Поэтому профсоюз: «категорически предлагает» своим отделениям: «вовлечь до 10\% существующего профактива в производственные кружки по повышению квалификации. <..> вовлечь в работу по организации этих кружков ИТС, созвав их специально по этому вопросу, строго наметив сеть и разработав программы кружков. <...> Признать необходимым организацию курсов счетных работников и курсов по языкам при союзе Совторгслужащих» (там же).

Современная историческая публицистика, посвященная периоду «Первых сталинских пятилеток», часто обращается к теме так называемых «лишенцев»- граждан из числа бывших представителей высших или зажиточных (кулачество) сословий Российской Империи, которые в период коллективизации подвергались так называемому «поражению в правах». Куда меньше вспоминают сегодня о том новом советском «сословии», которое, можно сказать, оказалось противопоставлено «лишенцам». Это были «выдвиженцы»-люди, выдвигавшиеся на руководящие посты в производстве 
и советской администрации из среды пролетариата и крестьянства. Как правило, они не обладали, да и не могли обладать, в силу своего происхождения, достаточным запасом знаний, грамотностью для того, чтобы занять ключевые посты. Поэтому работа над повышением их культурного уровня стала одной из главной в период индустриализации.

Снова обратимся к протоколам Президиума Орехово-Зуевского окружного совета профсоюзов, которые отмечали: «Задачи, поставленные пятилетним планом всего народного хозяйства, представляют новые требования к качеству работы государственного аппарата. Упрощение, удешевление аппарата, решительное изгнание из него бюрократизма, чиновничества, косности и волокиты, особенно в настоящий реконструктивный период, требуют успешного проведения социалистического строительства. Эти задачи могут быть выполнены при условии выдвижения сотен и тысяч передовых рабочих и работниц во всех звеньях государственного, кооперативного и профсоюзного аппарата. Рост культурного и политического уровня и активности рабочих масс облегчает более решительную борьбу с отрицательными явлениями в аппарате и обеспечивает возможность массового притока рабочих кадров в госаппарат» (там же).

В связи с этой задачей профсоюз считает нужным: «Выделить и подготовить 86 рабочих от станка для поступления в ВУЗы и ВТУЗы в 1930 г. При проведении намеченного плана выдвижения предложить окротделам союзов и ФЗМК обеспечить выдвижение не менее 35-40\% беспартийных, 25\% женщин и 10\% молодежи» (там же. Л. 19).

Простая арифметика приводит к выводу, что в общем числе этих новых выдвиженцев беспартийных оказывалось до 75 \%. Как-то не очень это укладывается в стойкое утверждение, бытующее ныне, о том, что для успешной карьеры в СССР необходимо было быть членом коммунистической партии. Хотя, естественно, что, войдя в административный «резерв» (да, именно это ныне популярное слово употребляется в исторических документах - О. Ж.), выдвиженец со временем мог стать и членом партии.

Однако, заслушав доклад «О выполнении разверстки в счет 1000 беспартийных во ВТУЗы», Президиум Окрпрофсовета констатировал «невыполнение данной разверстки, являющейся мероприятием огромной важности в деле подготовки красных пролетарских специалистов. <...> В дальнейшем президиум Окрпрофсовета постановляет провести следующие мероприятия: <...> всемерно развить сеть курсов и кружков по подготовке в ВУЗы и техникумы. Привлечь к организации и руководству этих курсов и кружков членов профсоюзов, имеющих высшее образование, особенно специальное. <...> Широко популяризировать среди рабочих заочный Ореховский рабфак» (там же).

Насколько широк был общий круг вопросов, касающихся культур- 
ного просвещения рабочих, можно судить по тем же протоколам заседаний Президиума Орехово-Зуевского окружного совета профсоюзов. В ноябре 1929 г. совет обсуждал доклады: «О состоянии изобретательства»; «О работе общества «Техника - массам»; «О культурном обслуживании безработных»; «О состоянии работы среди нацмен»; «О ходе выполнения программы по ликвидации неграмотности среди членов профсоюзов и в деревне» (ЦГАМО. Ф. 357. ОП. 1. Д. 1. Л. 33).

10 февраля 1930 г. на выездном совещании в богатую торфом Шатуру, обеспечивающую потребности в топливе текстильных и керамических предприятий Восточного Подмосковья, говорили среди прочего и «О состоянии и мерах развития самокритики» (там же).

А 21 февраля 1930 г. - «О постановке культработы союзов и профессиональном воспитании»; «О классовом интернациональном воспитании рабочих и борьбе с классово-чуждой идеологией пролетариату / антирелигиозная пропаганда, борьба с алкоголизмом, антисемитизмом/ и в этой связи о работе клубов и красных уголков»; «О постановке политпросветработы в деревне и строительстве сети пролитпросветучреждений в городе и деревне в разрезе пятилетки» (там же).

Масштабная коллективизация деревни с ее неоднозначно воспринятым обобществлением скотины и крестьянского инвентаря дает пищу для фантазии «креаторов» той поры. И вот уже рождается оригинальная идея библиотечных колхозов, в которых «обобществленная книга» становится всеобщим достоянием «бибколхозников». На заседании Президиума Орехово-Зуевского окружного совета профсоюзов 19 июля 1930 г. заслуживается доклад о работе бибколхоза, констатируются некоторые его достижения: «Расширение библиотечной сети, особенно непосредственное на фабриках и окраинах города. Улучшено обслуживание рабочих книгой, особенно политической, производственной и научно-популярной. Организовано единое руководство библиотечной работы» (там же. Д. 2, Л. 134).

Среди рекомендаций: Культсектору профсоюза: «помочь бибколхозу в деле организации библиотечной сети /особенно сети, обслуживающей сезонных рабочих/. Помочь бибколхозу в деле предоставления ему соответствующих помещений. Поставить вопрос перед заводоуправлением ф-ки «Пролетарская» о вхождении в бибколхоз, и предоставить для всеобщего потребления книги, до сих пор неиспользуемые рабочими и помещения для организации центральной технической текстильной библиотеки. Считать желательным организацию при библиотеке детской технической станции, мобилизовав в помощь ей ИТР. Указать всем секциям ИТР о необходимости оказания помощи бибколхозу в деле пропаганды производственной книги. Организовать выдвижение рабочих активистов на библиотечную работу. Организационно-инструкторскому 
сектору - организовать шефскую помощь над колхозом и отдельными библиотеками» (там же).

Самому же бибколхозу предписывается: «Увеличить количество актива непосредственно на фабриках и заводах. Расширить и улучшить сеть во всех городских культбазах /Парк культуры и отдыха, парк 1 Мая, Горпарк и др./ Расширить библиотечную сеть на фабриках, в казармах и в общежитиях» (там же).

Обсуждая Августовский пленум МОСПС, расширенный пленум Орехово-Зуевского райпрофсовета отмечает, что «новые успехи социалистического строительства выдвигают новые задачи перед профсоюзами <...> требуют <...> повседневной заботы о материальном и культурном обслуживании рабочих и работниц. Вопросы рабочего снабжения и питания должны стать в центре внимания профсоюзов. Такие задачи, как бесперебойность работы кооперативных организаций, работа ЗРК - устранение очередей, улучшение работы фабричного буфета и столовой, борьба за чистоту в последних, требуют от ФЗК постоянного внимания и организации рабочего контроля за подшефными магазинами, палатками, столовой, буфета и участками с/х комбината... Пленум Райпрофсовета предлагает Президиуму и ФЗК ввести в тему своей работы заботу о жилищах, банях и дет. яслях и садах. Борьба за чистоту в рабочем жилище, организация сети дошкольных учреждений, лучшая работа бань, организация новых красных уголков и библиотек. Все это должно стать важнейшими задачами борьбы за промфинаплан» (ЦГАМО. Ф. 326. Оп. 1. Д. 1. Л. 46).

Так, чистота окружающей среды и личная гигиена признаются важнейшими показателями культурной жизни населения: «Пленум обязывает Президиум провести декадник смотра работ бань, наметить мероприятия по устранению всех недостатков, а также обязать хозяйственников немедленно начать ремонт всех бань. <...> Организовать смотр всех казарм, выделив 2-3 казармы для постановки образцовой социально-бытовой и культурно-массовой работы в казарме» (там же).

...Октябрь 1932 г., Совещание председателей фабрично-заводских комитетов предприятий Орехово-Зуевского райсовета профсоюзов после неурожая того голодного года посвящено хлебу насущному, но удивительном образом переводит этот вопрос в культурной плоскость: «во избежание очередей в столовой № 1 во время обедов и для более удобного обслуживания детей подыскать помещения для столовой по районам: Крутовский район - магазин № 20 быв. Филиал. Зуевский - пивная. Новая стройка - Клуб нацмен» (ЦГАМО. Ф. 326. Оп. 1. Д. 4. Л. 24).

Культура становится неотделима от проблем повседневности. В эти же дни, готовясь к призыву молодых орехово-зуевцев в ряды Красной Армии, председатели фабрично-заводских комитетов предприятий Орехо- 
во-Зуевского райсовета профсоюзов постановляют: «Всем ФЗМК в день отправки обеспечить посылку бригад для проводов допризывников в ряды Красной Армии. ФЗК Подгорной фабрики обеспечить посылку оркестра на 10/X и 11/X-32 г. На местах провести вечера допризывников, посвященные проводам, обеспечив приобретение и выдачу подарков последним» (там же. Л. 21).

И одновременно с этим - о детском питании: «Всем ФЗК немедленно организовать тройки по отбору детей для питания в столовых, обратив особое внимание на отбор детей малообеспеченных родителей и ударников, выполняющих промфинплан». И такими, оказывается, могли быть пресловутые «тройки»...

...Проходили годы и десятилетия. Позади осталось время испытаний - революция, Гражданская война, Великая Отечественная, послевоенное восстановление народного хозяйства... Но в трудовых коллективах, на заседаниях фабрично-заводских комитетов по всему СССР вопрос о культуре быта и культуре производства традиционно оставался одним из самых значимых. В протоколе общего собрания членов профсоюза Мининской ткацкой фабрики, на которой работал в ту пору счетоводом мой прадед Иван Тимофеевич Жуков, датированном 25 сентября 1963 г. отмечается: «Низка культура производства. Загрязненность и захламленность в цехах производства до сих пор не изжита» (ЦГАМО. Ф. 378. Оп. 1. Д. 606. Л. 133) <...> «Все еще недостаточна культура производства, очень много пыли в оконных переплетах, не регулярно моются полы на 2-ом этаже, нет места для принятия пищи и хранения одежды, на что в какой-то мере сказывается теснота помещения» (там же. Л. 138).

Вместе с тем отмечается, что «проделана большая работа по улучшению культуры производства: побелка и покраска стен основного корпуса, красильного цеха, капитальный ремонт перекрытия котельной, замена оконных ран на производстве. Решен вопрос со снабжением цеха водой» (там же).

Фабрично-заводской комитет предлагает: «Шире развивать форму наглядной агитации и производственно-технической пропаганды. Больше вовлекать молодежи в проведение культурных мероприятий» (там же).

А в местном клубе молодые ткачихи, нарядившись в ярко-бирюзовые платья, расшитые бисером и пайетками, на фоне искусно нарисованной березовой рощи поют для своих односельчан старые русские и новые советские песни. Так же, как пели когда-то их матери и бабушки, тоже ткачихи.

И не знают еще, что через тридцать лет, после пресловутой «перестройки» и развала СССР, закроется их фабрика, восстановленная руками их отцов и матерей после потрясений Гражданской войны, работавшая 
на оборону в годы Великой Отечественной. Ее станки будут выброшены новыми хозяева-«кооператорами» прямо в окна. А в клубе дети и внуки ткачих разворуют и музыкальные инструменты, и кинооборудование. А еще - закроется почта, больница, ателье, школа-восьмилетка. И превратится их промышленная деревня Минино в дачный поселок, куда будут приезжать летом москвичи, скупившие дома у их потомков, и - сами потомки, ставшие горожанами...

\section{СПИСОК ЛИТЕРАТУРЫ}

История гражданской авиации СССР (1983). М. : Воздушный транспорт. 376 с.

Дата поступления: 15.11.2017 2.

Жукова Ольга Германовна - кандидат исторических наук, доцент кафедры истории и регионоведения Московского гуманитарного университета; член Союза писателей России и Союза журналистов Москвы. Адрес: 111395, Россия, Москва, ул. Юности, д. 5. Тел.: + 7 (499) 374-70-88. Эл. адрес: letchikova@mail.ru

Zhukova Olga Germanovna, Candidate of History, Associate Professor, Department of History and Regional Studies, Moscow University for the Humanities; Member, Writers' Union of Russia; Member, Journalists' Union of Moscow. Postal address: 5, Yunosti St., Moscow, Russian Federation 111395. Tel.: + 7 (499) 374-70-88. E-mail: letchikova@mail.ru

\section{Для цитирования:}

Жукова О. Г. Культурный фронт Гражданской войны (по материалам Центрального государственного архива Московской области) [Электронный ресурс] // Научные труды Московского гуманитарного университета. 2017. № 6.URL: http://journals.mosgu. ru/trudy/article/view/623 (дата обращения: дд.мм.гг.). DOI: 10.17805/trudy.2017.6.7 